\title{
PENGARUH RAPAT ARUS ANODIZING TERHADAP NILAI KEKERASAN PADA PLAT ALUMINIUM PADUAN AA SERI 2024-T3
}

\author{
Fajar Nugroho
}

\author{
Teknik Mesin \\ Sekolah Tinggi Teknologi Adisutjipto \\ Jalan Janti Blok-R Lanud Adisutjipto, Yogyakarta \\ mas_noeg@yahoo.com
}

\begin{abstract}
Aluminum alloy AA 2024-T3 is widely applied in the aircraft industry because it has good mechanical properties such as; light weight, good conductivity and the corrosion resistance. However Aluminium 2024-T3 susceptible to wearing. One method to improve the wear resistance of $A A 2024-T 3$ is the anodizing process. The aims of this research to study the effect of current density and anodizing time against the hardness of aluminum alloy AA 2024-T3.

The process of anodizing was carried out using 10 percent sulfuric acid solution with the current density of 1.5 Ampere per decimeters square, 3.0 Ampere per decimeters square and 4.5 Ampere per decimeters square with immersion times of 30, 40, 50 and 60 minutes. Furthermore, the surface hardness was measured by using the Vickers hardness test method. As the supporting data the composition of the test conducted, testing the microstructure, and vickers hardness test.

This study shows that the surface hardness of aluminum alloy AA 2024-T3 is influenced by the current density and anodizing time with varying values. Its shows that higher current density of the anodizing caused optimal time tends to be short. The longer anodising time it will produce greater layer of aluminum oxide.
\end{abstract}

Keywords: aluminium alloy AA 2024-T3, anodizing, current density, time, hardness

Abstrak

Aluminium seri 2024-T3 diaplikasikan secara luas pada industri pesawat terbang karena memiliki sifat mekanik yang baik seperti; bobot yang ringan, konduktivitas yang baik dan adanya ketahanan korosi yang cukup baik. Namun demikian Aluminium 2024-T3 rentan terhadap keausan. Salah satu cara untuk meningkatkan ketahanan aus adalah dengan proses anodizing. Penelitian ini bertujuan mempelajari pengaruh rapat arus dan waktu anodizing terhadap nilai kekerasan aluminium AA 2024-T3.

Proses anodizing menggunakan larutan asam sulfat 10 persen dengan rapat arus antara 1,5 Ampere per desimeter persegi, 3 Ampere per desimeter persegi dan 4,5 Ampere per desimeter persegi dengan waktu pencelupan 30, 40, 50 dan 60 menit. Selanjutnya benda uji diuji kekerasan permukaannya, dan diuji struktur mikronya. Data pendukung dari penelitian ini adalah uji komposisi, uji struktur mikro dan uji kekerasan vickers.

Hasil penelitian ini menunjukan bahwa nilai kekerasan pelat aluminium paduan AA 2024-T3 dipengaruhi oleh rapat arus dan waktu anodizing dengan nilai yang bervariasi. Rapat 
arus semakin besar maka waktu optimal anodizing cenderung semakin singkat. Semakin lama waktu anodizing maka akan dihasilkan lapisan aluminium oksida yang semakin besar.

Kata kunci: aluminium paduan 2024-T3, anodizing, rapat arus, waktu, kekerasan

\section{Pendahuluan}

Aluminium merupakan material yang digunakan secara luas di industri karena memiliki beberapa keunggulan dibanding dengan material lain yaitu aluminium merupakan logam ringan, konduktivitas panas dan listrik tinggi. Aluminium juga memiliki sifat mampu mesin (machinabillity) dan sifat mampu cor (castabllity) baik, serta tahan terhadap korosi.

Salah satu jenis aluminium paduan yang banyak digunakan adalah aluminium paduan seri 2024-T3 yang merupakan paduan logam Al-Cu dengan 3,8-4,9\% tembaga, sedang T3 adalah proses perlakuan panas yang terdiri dari pelarutan padat (solid solution), quenching dan proses aging untuk mencapai tingkat kekerasan yang lebih baik (Polmear, 1981). Logam paduan ini biasanya digunakan untuk aplikasi pada struktur pesawat terbang seperti permukaan badan pesawat, permukaan dinding pesawat dan permukaan sayap bagian bawah (Staley dan Lege, 1993). Namun demikian aluminium paduan seri 2024-T3 rentan terhadap keausan yang disebabkan tingkat kekerasan yang relatif rendah.

Beberapa komponen yang bekerja pada lingkungan abrasif dan bersinggungan dengan material lain cenderung lebih cepat aus. Proses tersebut disebabkan oleh rusaknya lapisan aluminium oksida pada permukaan aluminium yang sangat mempengaruhi dari nilai kekerasan. Penelitian ini akan mempelajari pengaruh rapat arus dan waktu proses anodizing terhadap nilai kekerasan AA 2024-T3.

Proses anodizing mempunyai peranan yang penting dalam industri manufaktur, seperti industri mesin, perakitan kendaraan bermotor, industri pesawat terbang dan barangbarang logam lainya. Anodizing dilakukan untuk mendapatkan lapisan oksida yang lebih tebal dan seragam pada permukaan aluminium. Beberapa penelitian dengan obyek penelitian anodizing telah dilakukan antara lain sebagai berikut. Shulgov dkk. (2006) melakukan penelelitian tentang hubungan kondisi pembentukan lapisan aluminium oksida dengan tegangan breakdown. Hasil dari peneletian ini menunjukan bahwa besarnya tegangan breakdown tergantung pada larutan elektrolit pada saat proses anodizing. Apachitei dkk. (2006) meneliti pengaruh komposisi subtrat, rapat arus, perubahan tegangan dan temperatur selama proses anodizing. Hasil dari penelitian ini menunjukan bahwa temperatur elektrolit meningkat dengan meningkatnya rapat arus yang digunakan, sedang ketebalan lapisan yang dihasilkan lebih dipengaruhi oleh besarnya tegangan anodizing dan tidak tergantung pada subtrat. Vrublevsky dkk. (2007) melakukan penelitian tentang mekanisme pertumbuhan lapisan oksida aluminium yang porous dengan larutan elekrolit asam sulfat. Hasil dari penelitian ini menunjukan bahwa porositas yang dihasilkan dalam lapisan tidak dipengaruhi oleh besarnya tegangan anodizing tetapi lebih dipengaruhi oleh jenis material dari substrat. Mukhurov dkk. (2008) menyelidiki pengaruh komposisi larutan elektrolit pada proses anodizing aluminium. Hasil dari penelitian ini menunjukan bahwa ketebalan lapisan aluminium oksida yang dihasilkan sangat bervariasi tergantung pada jenis dan komposisi elektrolit yang digunakan. Dalam penelitian ini juga disebuatkan bahwa ketebalan yang dihasilkan juga disebabkan oleh adanya perbedaan temperatur elektrolit. Saeler dkk. (2009) meneliti perilaku dari fretting pada paduan Al 2014-T6 setelah dilakukan proses anodizing. Hasil dari penelitian ini menunjukan bahwa setelah proses anodizing kekerasannya 
meningkat secara signifikan dari 175 VHN menjadi 380 VHN dan ketahanan terhadap fretting juga meningkat. Pooladi dkk. (2009) meneliti proses anodizing aluminium seri 1100 dengan variabel tegangan anodizing dan waktu anodizing. Hasil dari penelitian ini menunjukan bahwa lapisan aluminium oksida yang dihasilkan tergantung pada temperatur elektrolit, rapat arus, dan proses polishing dari permukaan subtrat. Selanjutnya Masruri (2010) menyelidiki pengaruh variasi konsentrasi elektrolit dan rapat arus pada proses anodizing aluminium seri 1xxx. Hasil dari penelitian ini menunjukan bahwa kekerasan meningkat secara signifikan sebesar $\pm 20 \%$ pada larutan elektrolit $10 \%$ asam sulfat dengan rapat arus $3 \mathrm{~A} / \mathrm{dm} 2$ dan ketahanan terhadap korosi juga meningkat. Soekrisno (2012) melakukan penelitian tentang proses optimalisasi temperatur hard anodizing terhadap ketahanan aus, kekerasan serta ketebalan lapisan oksida aluminium paduan. Hasil dari penelitian ini adalah bahwa kekerasan aluminium paduan akan meningkat dengan meningkatnya suhu elektrolit dengan ketebalan lapisan oksida yang semakin tebal. Nugroho (2014) melakukan penelitian tentang pengaruh variasi rapat arus dan waktu anodising terhadap ketebalan lapisan aluminium oksida pada AA 2024 T3. Dari penelitian ini dapat disimpulkan bahwa ketebalan lapisan aluminium oksida akan meningkat dengan meningkatnya rapat arus dan lama waktu pencelupan dalam larutan elektrolit. Ketebalan lapisan aluminium oksida mencapai nilai optimun berkisar $10 \mu \mathrm{m}-15 \mu \mathrm{m}$.

Dari kajian pustaka yang telah dilakukan, peneliti sebelumnya pada umumnya lebih fokus pada hubungan antara pengaruh proses anodizing terhadap ketebalan lapisan aluminium oksida yang dihasilkan dengan beberapa parameter seperti temperatur, waktu, rapat arus komposisi larutan dan pre treatment. Namun sejauh ini belum banyak penelitian yang secara khusus menyelidiki pengaruh waktu dan rapat arus anodizing terhadap kekerasan pada aluminium paduan AA 2024-T3.

\section{Metode Penelitian}

Dalam penelitian ini dilakukan karakterisasi material untuk memastikan jenis material yang digunakan merupakan AA 2024-T3. Jenis pengujian karakterisasi material yang digunakan antara lain; uji komposisi, uji struktur mikro dan uji kekerasan.

- Uji Komposisi Material

Uji komposisi material dilakukan dengan menggunakan spektrometer yang bertujuan untuk mengetahui jenis dan spesifikasi dari material yang digunakan.

\section{- Pengamatan Struktur Mikro}

Pengamatan struktur mikro dilakukan pada tiga bidang yaitu permukaan, melntang dan membujur. Preparasi spesimen dengan cara dipoles dan dietsa dengan cairan kimia Keller's reagent selama 10-20 detik.

\section{- Pengujian kekerasan}

Pengujian kekerasan dilakukan untuk mengetahui kekerasan awal dan kekerasan setelah spesimen mengalami proses anodizing. Peralatan yang digunakan untuk uji kekerasan Buehler Microhardness Tester dengan metode Vickers.

Selanjutnya material spesimen dilakukan proses anodizing. Spesimen uji adalah Aluminium paduan 2024-T3 dengan dimensi $100 \mathrm{~mm}$ x $40 \mathrm{~mm}$ x 1,7 mm. Preparasi dilakukan berturut-turut adalah degreasing, pickling, fluxing, strike dan anodizing. Pembersihan dilakukan dengan merendam spesimen uji dalam larutan $\mathrm{NaOH}$ kadar $5-10 \%$ selama 10 sampai 20 menit. Pembersihan spesimen uji dari scale (pickling) dilakukan 
dengan merendam dalam larutan asam sulfat (5 sampai $15 \%$ ). Pembersihan permukaan spesimen uji dari sisa-sisa asam sulfat sehabis proses pickling, dilakukan dengan merendam spesimen uji dalam larutan air sabun (fluxing) sehingga terjadi proses penetralan asam oleh sabun dengan temperatur air $\pm 50^{\circ} \mathrm{C}$. Hasil dari pengamatan dan pengujian akan disajikan dalam bentuk tabel maupun grafik. Selanjutnya akan dianalisa seberapa besar pengaruh densitas arus proses anodizing mampu meningkatkan nilai kekerasan pada material aluminium seri 2024-T3.

\section{Hasil dan Pembahasan}

\subsection{Karakterisasi Material}

Pengujian komposisi kimia digunakan untuk mengetahui komposisi bahan spesimen. Hasil uji komposisi dibandingkan dengan komposisi material standar seperti terlihat pada Tabel 1. Dari hasil uji komposisi yang telah dilakukan menunjukan bahwa spesimen yang digunakan dalam penelitian ini mempunyai komposisi yang masuk dalam batasan dari komposisi material standar aluminium paduan AA 2024-T3.

Tabel 1. Komposisi Kimia

\begin{tabular}{|c|c|c|c|c|c|c|c|c|c|}
\hline Unsur & $\mathbf{S i}$ & $\mathbf{F e}$ & $\mathbf{C u}$ & $\mathbf{M n}$ & $\mathbf{M g}$ & $\mathbf{Z n}$ & $\mathbf{C r}$ & $\mathbf{T i}$ & $\mathbf{A l}$ \\
\hline $\begin{array}{c}\text { Standar } \\
\text { (Wt. \%)) }\end{array}$ & $\leq 0,5$ & $\leq 0,5$ & $3,8-4,9$ & $0,3-0,9$ & $1,2-1,8$ & $\leq 0,25$ & $\leq 0,1$ & $\leq 0,15$ & $90,7-94,7$ \\
\hline $\begin{array}{c}\text { Spesimen } \\
\text { (Wt. \%) }\end{array}$ & 0,5 & 0,5 & 3,9 & 0,6 & 1,5 & 0,25 & 0,1 & 0,15 & 92,5 \\
\hline
\end{tabular}

Pengujian karakterisasi kekerasan vickers aluminium paduan AA 2024-T3 dilakukan pada bidang permukaan, membujur dan melintang plat. Hasil dari pengujian kekerasan pada raw material yang memberikan hasil masing-masing sebesar $136 \mathrm{VHN}, 118 \mathrm{VHN}$ dan 135 VHN. Hasil pengujian tersebut masih dalam batasan material standar.

Hasil uji struktur mikro AA 2024-T3 pada berbagai posisi pengamatan terlihat seperti Gambar 1. Gambar 1(a) merupakan foto struktur mikro pada permukaan bidang pelat, dan pada gambar tersebut terlihat bahwa bentuk butiran berupa equi-axial sedangkan pada bidang membujur (Gambar 1(b)) dan melintang (Gambar 1(c)) bentuk butirannya berbentuk lebih pipih atau memanjang. Perbedaan bentuk butiran pada bidang orientasi yang berbeda ini kemungkinan disebabkan oleh adanya pengaruh gaya yang bekerja pada saat proses pengerolan pembentukan pelat paduan AA 2024-T3.

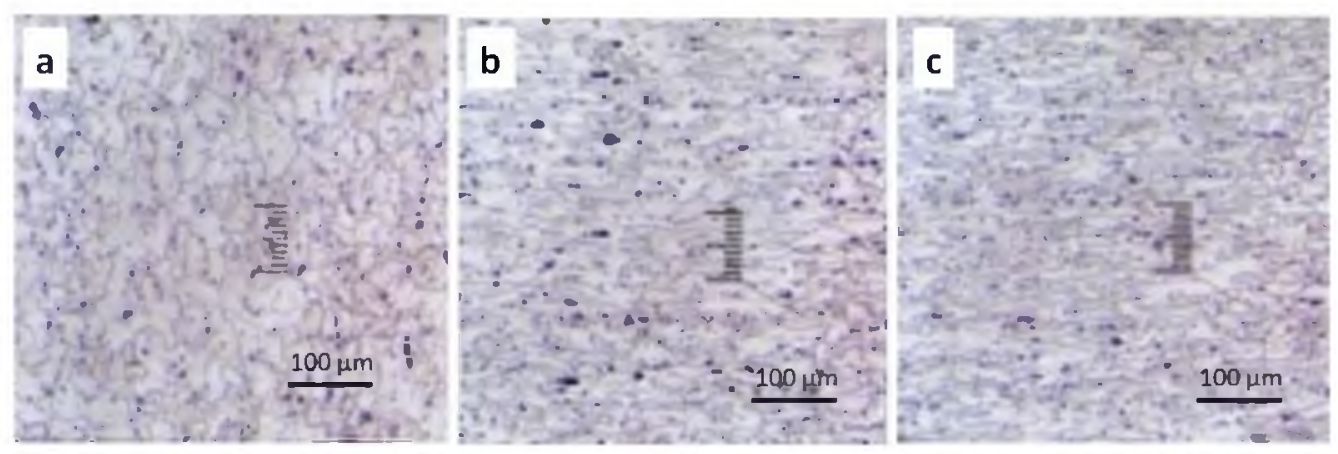

Gambar 1. Struktur mikro AA 2024-T3: (a ) permukaan, (b) membujur, (c) melintang 
Pengamatan struktur mikro juga menunjukan adanya partikel halus berupa inklusi (warna gelap). Adanya inklusi ini kemungkinan merupakan oksida dalam bentuk ikatan senyawa $\mathrm{Al}$ dengan $\mathrm{Cu}, \mathrm{Fe}, \mathrm{Mg}, \mathrm{Mn}$, Si dan unsur-unsur lainnya.

Dari pengujian karakterisasi material yang telah dilakukan menunjukan bahwa material yang digunakan dalam penelitian ini adalah benar-benar merupakan material pelat aluminium paduan AA 2024-T3.

\subsection{Hasil Uji Kekerasan.}

Pengujian kekerasan suatu bahan bertujuan untuk mengetahui ketahanan suatu bahan terhadap deformasi plastis apabila bahan tersebut diberi beban dari luar. Pengujian kekerasan dilakukan pada spesimen material dasar dan spesimen yang telah mengalami proses Aonodizing. Nilai kekerasan Vickers dihitung dari beban yang digunakan dan juga diagonal rata-rata bekas injakan indentor yang kemudian dimasukkan kedalam persamaan penghitungan nilai kekerasan. Penguji kekerasan ini dilakukan dengan mengambil data sebanyak 10 titik pada setiap permukaan spesimen. Hasil perhitungan nilai kekerasan Vickers yang telah didapat kemudian dibuat grafik dari nilai kekerasan material dasar dan juga nilai kekerasan dari material yang telah mengalami proses anodizing pada variasi kuat arus dan waktu pencelupan.

Gambar 2 merupakan grafik perbandingan hasil nilai kekerasan material dasar dengan material yang telah mengalami proses anodizing dengan variasi waktu pencelupan anodizing. Dari gambar tersebut memperlihatkan bahwa nilai kekerasan secara umum akan meningkat dengan semakin lamanya waktu pencelupan di dalam larutan elektrolit. Peningkatan kekerasan ini terjadi pada semua variasi arus yang digunakan. Semakin lama proses anodizing yang dilakukan akan menyebabkan lapisan aluminium oksida pada spesimen akan semakin tebal.

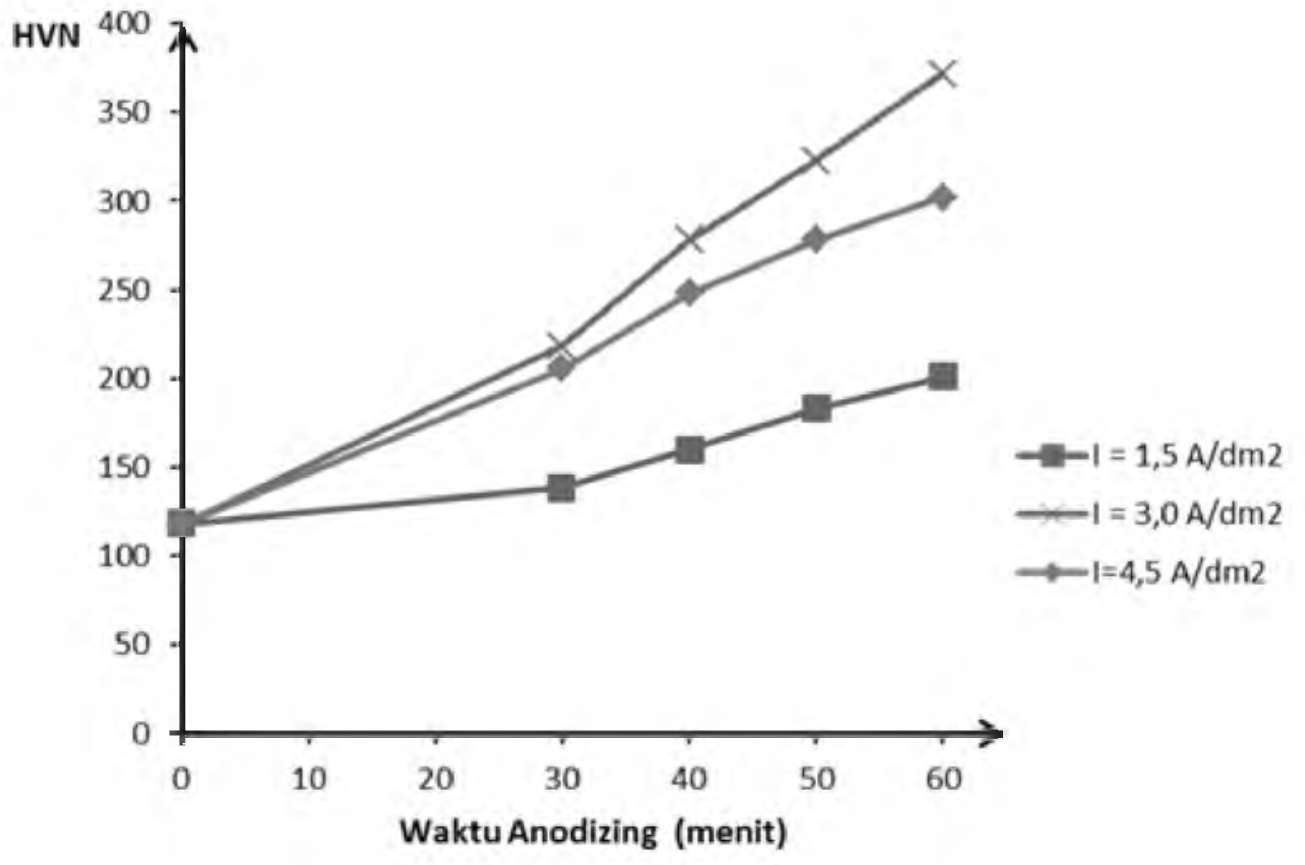

Gambar 2. Nilai kekerasan pada variasi waktu anodizing. 
Gambar 3 merupakan hasil uji kekerasan pada variasi rapat arus. Dari gambar tersebut terlihat bahwa nilai kekerasan material akan meningkat dengan semakin besarnya rapat arus proses anodizing. Dalam proses anodizing kuat arus berfungsi sebagai pemindah ion-ion $\mathrm{Al}$ untuk yang membentuk lapisan aluminium oksida yang menempel pada spesimen. Semakin tinggi kuat arus maka semakin cepat ion-ion aluminium oksida yang menempel pada permukaan spesimen, sehingga lapisan aluminium oksida lebih padat yang menyebabkan kerapatan permukaan pada spesimen meningkat. Sebagai hasilnya, kekerasan pada permukaan spesimen yang telah mengalami proses pelapisan mengalami peningkatan. Hal ini sesuai dengan penelitian yang dilakukan Sukrisno (2012) dan Saeler (2009) yang melaporkan bahwa peningkatan nilai kekerasan dari material aluminium setelah proses anodizing.

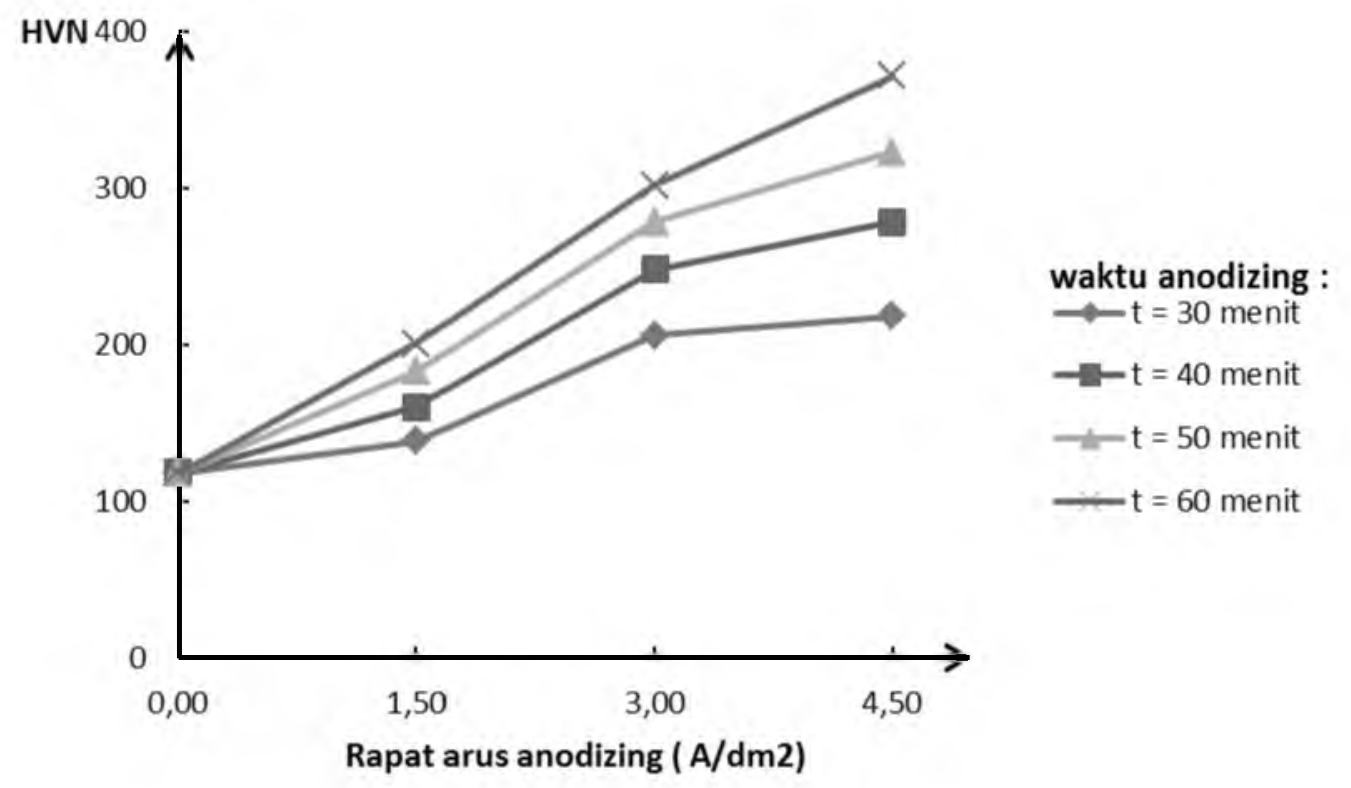

Gambar 3. Nilai kekerasan pada variasi rapat arus anodizing

\subsection{Hasil Uji Struktur Mikro Setelah Anodizing}

Aluminiun paduan AA 2024-T3 tanpa perlakuan proses anodizing memiliki lapisan aluminium oksida yang tipis dengan permukaan terlihat seperti pada Gambar 4(a). Dari pengamatan hasil foto SEM menunjukan bahwa pada permukaan AA 2024-T3 tanpa anodizing terlihat rata. Jika dibandingkan dengan Gambar 4(a), hasil foto SEM AA 2024-T3 setelah anodizing seperti terlihat pada Gambar 4(b), memperlihatkan adanya lapisan permukaan yang tidak merata dan bersifat porous atau berpori-pori. Permukaan yang berpori merupakan karakteristik dari material yang mengalami proses anodizing.

Gambar 4(b) menunjukan pelat aluminium paduan AA 2024-T3 setelah proses anodizing dengan rapat arus 3,00 A/dm2 dengan waktu pencelupan selama 60 menit. Pengamatan terhadap foto SEM permukaan menunjukan adanya bentuk lapisan aluminium oksida. Bentuk lapisan aluminium oksida yang terbentuk berupa lapisan yang berpori-pori dan tidak merata pada permukaan. 


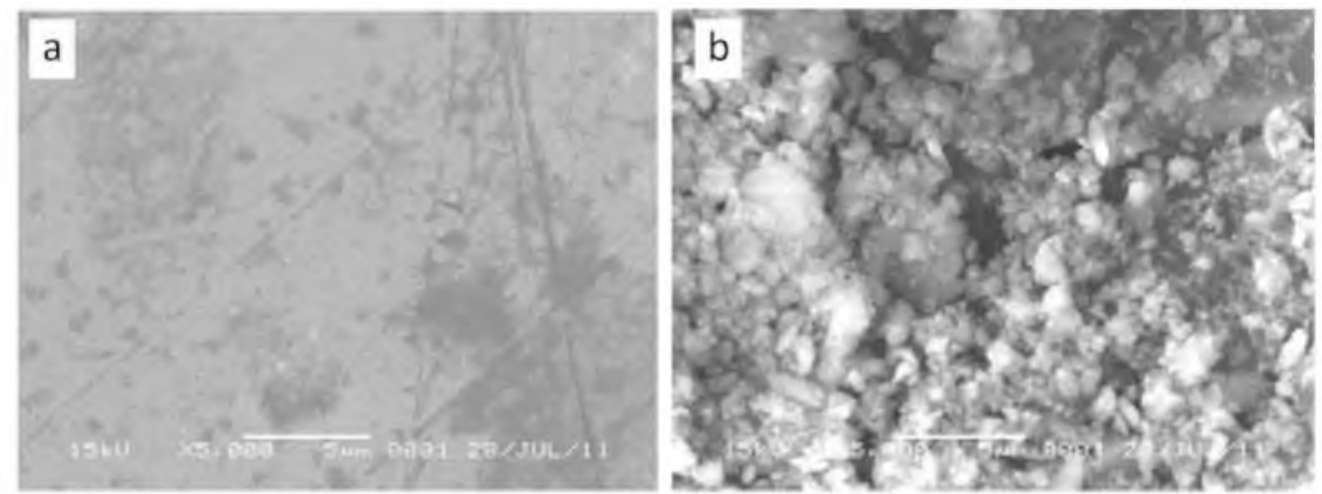

Gambar 4. Foto SEM permukaan AA 2024-T3

(a) tanpa anodizing, (b) dengan anodizing

Proses anodizing yang semakin lama menyebabkan pori-pori bertambah semakin banyak dan ukuran pori-pori semakin besar. Perubahan besarnya ukuran dan jumlah pori-pori yang terbentuk setelah proses anodizing pada permukaan pelat paduan AA 2024-T3 dapat dilihat pada Gambar 5. Pada proses anodizing dengan rapat arus, $50 \mathrm{~A} / \mathrm{dm} 2$ telah terbentuk lapisan aluminium oksida pada permukaan AA 2024-T3 dengan jumlah pori-pori yang relatif kecil. Selanjutnya untuk proses anodizing yang lebih lama menyebabkan bertambahnya jumlah pori-pori yang terbentuk pada lapisan aluminium oksida.

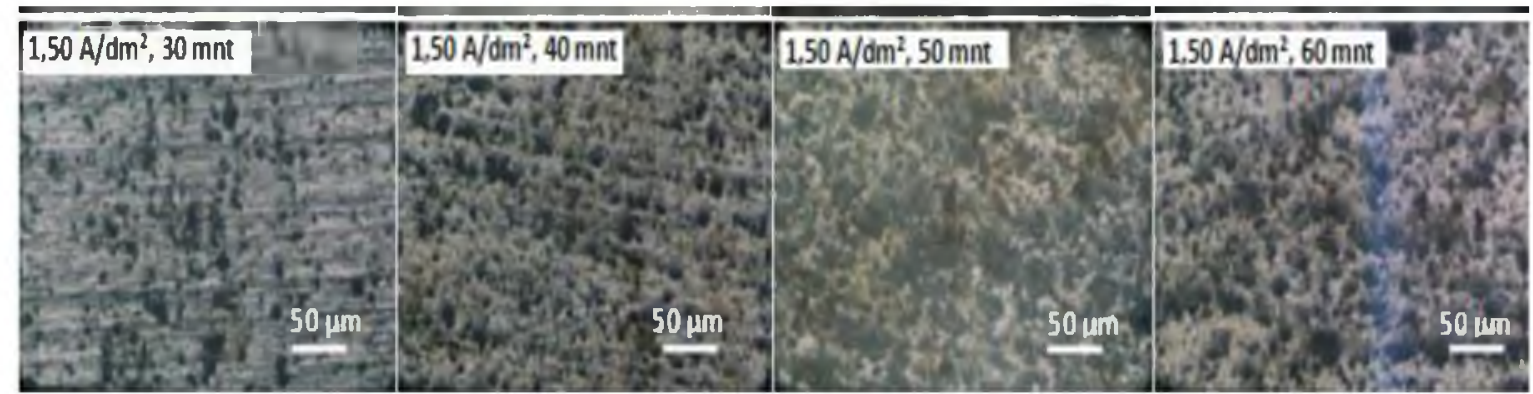

Gambar 5. Foto mikro hasil anodizing untuk rapat arus $1,50 \mathrm{~A} / \mathrm{dm} 2$

Proses anodizing dengan rapat arus yang semakin besar ternyata juga memberikan hasil memiliki kecenderungan yang sama, yaitu semakin besar rapat arus yang digunakan pada proses anodizing maka akan menghasilkan pori-pori dalam jumlah yang lebih besar. Hal ini dapat dilihat pada Gambar 6. Dari gambar tersebut dapat dilihat kecenderungan pembentukan lapisan aluminium oksida yang semakin tebal.

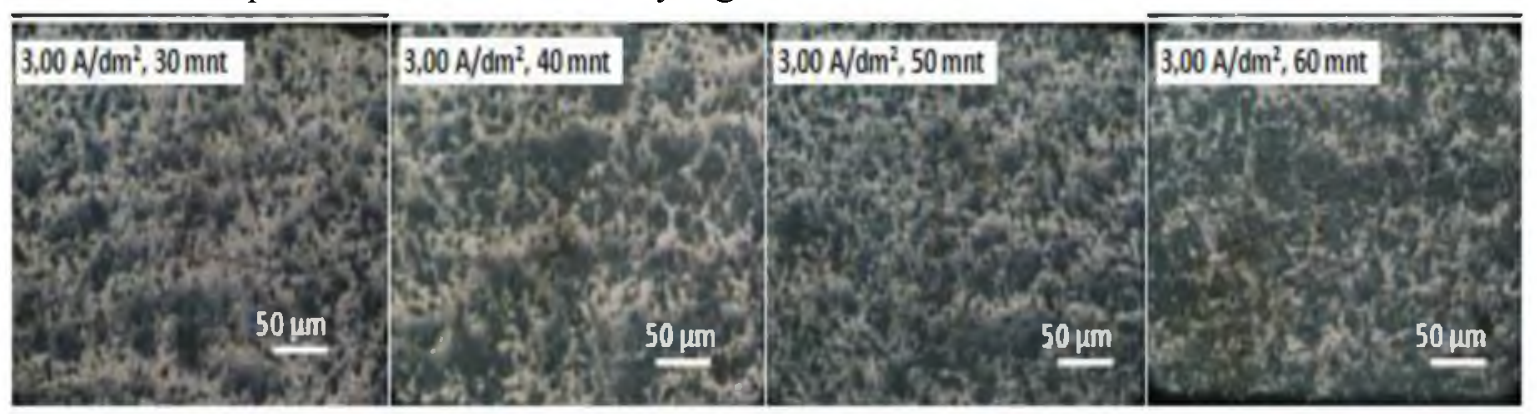

Gambar 6. Foto mikro hasil anodizing untuk rapat arus 3,00 A/dm2 
Ukuran dan jumlah pori-pori pada proses anodizing aluminium merupakan indikasi terbentuknya lapisan aluminium oksida. Namun demikian pengamatan struktur mikro permukaan lapisan aluminium oksida yang dihasilkan menunjukan adanya permukaan lapisan yang tidak rata. Ketidakrataan lapisan aluminium oksida ini disebabkan adanya arus dan energi yang berlebihan sehingga terjadi proses peluruhan kembali lapisan aluminium oksida ke dalam larutan elektrolit yang cukup besar, dan menyebabkan terbentuknya pori-pori pada lapisan aluminium oksida yang terlalu besar. Lapisan aluminium oksida yang terbentuk ini sangat berpengaruh pada sifat kekerasan permukaan material pelat aluminium paduan AA 2024-T3. Namun demikian, jika pori-pori yang dihasilkan terlalu besar atau melewati ukuran optimumnya maka akan menyebabkan permukaan lapisan aluminium oksida tidak rata, meskipun demikian jika dibandingkan dengan row material masih tetap memiliki kekerasan yang jauh lebih tinggi.

Gambar 7 merupakan foto SEM penampang pada spesimen AA 2024-T3. Dari pengamatan foto SEM terlihat bahwa proses anodizing menghasilkan lapisan aluminium oksida yang cukup tebal. Namun demikian lapisan yang dihasilkan tidak merata tetapi berpori-pori. Ukuran sel, jumlah pori per satuan luas tergantung pada jenis elektrolit, rapat arus, temperatur operasi elektrolit dan waktu anodizing yang digunakan. Anodizing dengan menggunakan larutan elektrolit asam sulfat secara teoritis bisa menghasilkan pori-pori hingga $4,98 \times$ E1 1 untuk setiap meter persegi.

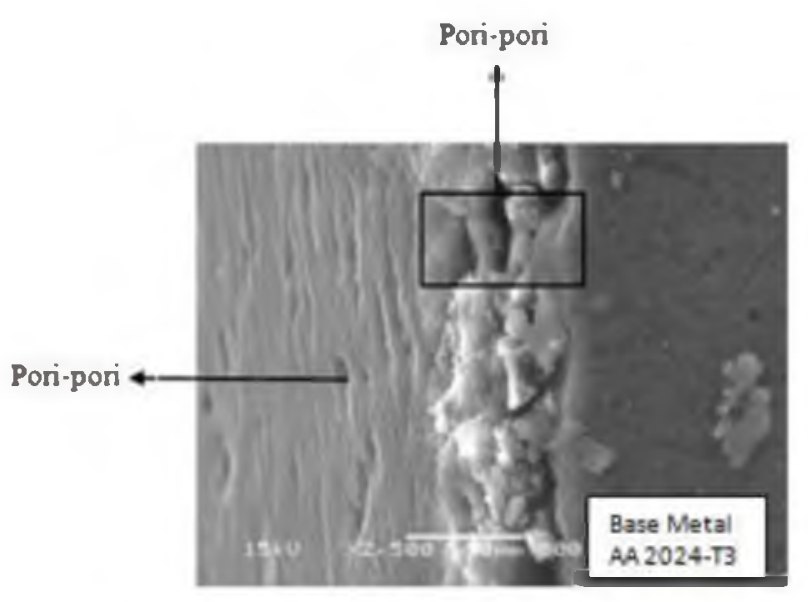

Gambar 7. Foto SEM penampang Al 2024-T3

\section{Kesimpulan}

Dari penelitian yang telah dilakukan dan pengamatan serta pembahasan terhadap parameter yang digunakan maka dapat diambil kesimpulan penelitian sebagai berikut :

a. Nilai kekerasan pelat aluminium paduan AA 2024-T3 dipengaruhi oleh rapat arus dan waktu anodizing dengan nilai yang bervariasi.

b. Rapat arus anodizing semakin besar maka waktu optimal anodizing cenderung semakin singkat.

c. Semakin lama waktu anodizing maka akan dihasilkan lapisan aluminium oksida yang semakin besar dengan nilai kekerasan yang semakin meningkat. Pengantar 


\section{Daftar Pustaka}

ASM Handbook, 1992, Corrosion, Metal Handbook, Vol.13.

ASTM, 2003, Metal Test Methods and Analitycal Procedurs, Anual Book of ASTM Standard, sc.3 Vol 03.01,E647-00, pp.615-657, Bar Harbor Drive Weat Conshohocken.

Apachitei, L.EF., Apachitei, I., Duszczyk, 2006, Thermal Effects Associated with Hard Anodizing of Cast Aluminum Alloys, Journal of Aplied Electrochemistry, Vol. 36, pp. 481-486.

Bardal, E., 2003, Corrosion and Protection, Springer-Verlag London, pp. 256

Callister, W.D., 2007, Material Science and Engineering an Introduction ", $7^{\text {th }}$ edition, John Willey.

Canning, W., 1970, Canning Hand Bookon Elektroplating, 2nd edition, pp. 695-706

Choi, J., 2003, Fabrication of Monodomain Porous Alumina Using Nanoimprint

Lithography and Its Application"s, desertation, Martin-Luther-Universit" at HalleWittenberg.

Fontana, M.G., 1986, Corrosion Engineering, McGraw-Hill, $3^{\text {th }}$ edition, New York.

Hatch, E.J., 1984, Alumimum Properties and Physical Metallurgy, Ohio, American Society for Metal.

Jones, D.A., 1991, Principle and Prevention of Corrosion, Mc. Millan Publishing Company, New York.

Mandal, N.R., 2005, Aluminum Welding, New Delhi, Narosa Publishing House.

Masruri, D., 2010, Pengaruh Variasi Konsentrasi Larutan Asam Sulfat dan Rapat Arus Terhadap Kekerasan, Struktur Mikro, dan Ketahanan Korosi Hasil Proses anodisasi Aluminium, Thesis, Universitas Gadjah Mada

Mukhurov, N.I., Zhvayi, S.P., Terekhov, S.N., 2008, Influence of Electrolyte Composition on Photoluminescent Properties of anodic Aluminum Oxide, Journal of Aplied Spectroscopy, Vol.75, pp. 214-217

Nugroho,F., 2014, Pengaruh Rapat Kuat Arus dan Waktu Anodizing Terhadap Laju Keausan Plat Aluminium Paduan AA 2024 T3, Jurnal Foundry, Vol.4

Pooladi, R., Rezai, H., Aezami, M., Sayyar, M.R., 2009, Fabrication of Anodic Aluminum Oxide Nanotemplate and Investigation of Their Anodization Parameters, Transaction of Indian Institute of Metals, Vol. 62, Issue 3, pp. 241-244.

Polmear, I.J., 1981, Light Alloy, $3^{\text {th }}$ edition Arnold, London

Sadeler, R., Atasoy, S., Arici, A., and Totik, Y., 2009, The Fretting Fatigue of Comercial Hard Anodized Aluminum Alloy, ASM International, Journal of Material Engineering and Performance, Vol 19., pp. 1280-1283.

Shulgov, V., Ignasheve, E., Gurskaja, E., 2007,Correlation Between Formation Condition and Breakdown Voltage of Anodic Films on Aluminum, Michrochimica Acta, Springer-Verlag, pp. 147-150.

Soekrisno,R., 2012, Optimalisasi Temperatur Hard Anodizing terhadap Ketahanan Aus, Kekerasan serta Ketebalan Lapisan Oksida Aluminium Paduan, Hasil Penelitian Hibah Prodi S2 Teknik Mesin JTMI FT UGM.

Staley, J.T. and Lege, D.J., 1993, Advanced in Aluminum Alloy Product For Struktural Application in Transportation, Journal De Physique III, 3, 197-190.

Trethewey, K.R., \& Chamberlain, J., Korosi Untuk Mahasiswa dan Rekayasa, PT.Gramedia Pustaka Utama, Jakarta. 
Fajar Nugroho

Vrublevsky, I., Parkoun, V., Sokol, V., Schreckenbach, J., Goedel, W.A., 2007, Dissolution Behaviour of Anodic Oxide Film Formed in Sulfanic Acid on Aluminum, Michrochimica Acta, Springer-Verlag, pp. 173-179. 